DOROTA DRZEWIECKA

(Uniwersytet Mikołaja Kopernika w Toruniu, Instytut Historii i Archiwistyki)

\title{
ARCHIVES OF POLISH UNIVERSITIES WITH REGARDS TO LAW REGULATIONS
}

The archives of universities are an important and extraordinary branch of the Polish archival network. They exist as current archives $^{1}$, which are the units occupied with the records not necessary for current tenure in the relevant institute. Besides, in many cases, they might play the role of state archives, thus they gather, keep, elaborate and give access to archival materials. All the public colleges and many private ones have their own archives.

Before I characterize current law regulations concerning the system and functioning of university archives, let me summarize briefly the Polish higher education system, just to give you the picture of the phenomenon examined.

1 In English nomenclature we can meet also: records current; in Polish archiwum zakładowe, in German Behördenarchiv, in French archives courantes; see: Polski Słownik Archiwalny [Polish Archival Dictionary], ed. by W. Maciejewska, (1974), pp. 100, 102, 110. 
The Polish higher education system is divided into two sections: the public and the private. The public section includes university-type higher education institutions (offering studies in humanities, sciences, medical sciences, economics, pedagogy, arts and military studies) and professional higher education institutions (which educate students in specific professional areas and prepare them for practicing a profession), whereas the private section includes all non-public academies, including church ones (though some of them have a license of a state unit) ${ }^{2}$.

There are 95 public universities supervised by the Minister of Higher Education in Poland. Among this number, we can distinguish 18 universities, 17 technical universities, 5 economic universities, 6 higher colleges of pedagogy, 6 agricultural universities, 6 academies of physical education, 2 theological academies ${ }^{3}$ and 36 state professional training collages ${ }^{4}$. We have to add 13 medical universities, 3 public theatrical universities ${ }^{5}, 8$ musical universi-

2 M. Barcik, Miejsce i znaczenie archiwów uczelnianych $w$ służbie archiwalnej [Place and meaning of the archives of universities in archival service], "Archiwista Polski", 3-4 (2001), p. 147; see also: http://www.nauka.gov.pl/ szkolnictwo-wyzsze/system-szkolnictwa-wyzszego/uczelnie/ (visited on 30 August 2010).

3 Publiczne uczelnie akademickie [Public academic universities], available on the Internet: http://www.nauka.gov.pl/szkolnictwo-wyzsze/system-szkolnictwa-wyzszego/uczelnie/uczelnie-publiczne/wykaz-uczelni-publicznychnadzorowanych-przez-ministra-wlasciwego-ds-szkolnictwa-wyzszego/publiczne-uczelnie-akademickie/ (visited on 4 June 2010).

4 Państwowe Wyższe Szkoły Zawodowe [State Professional Training Colleges], available on the Internet: http://www.nauka.gov.pl/szkolnictwo-wyzsze/ system-szkolnictwa-wyzszego/uczelnie/uczelnie-publiczne/wykaz-uczelnipublicznych-nadzorowanych-przez-ministra-wlasciwego-ds-szkolnictwawyzszego/panstwowe-wyzsze-szkoly-zawodowe/ (visited on 4 June 2010).

5 Wykaz uczelni artystycznych [List of artistic universities], available on the Internet: http://www.mkidn.gov.pl/pages/strona-glowna/uczniowie-i-studenci 
ties $^{6}$ and 7 academies of art $^{7}$. To sum up, we have 130 public universities in Poland.

While describing Polish higher school system, we cannot avoid the topic of higher schools which are dependent on the Ministry of National Defense and the Ministry of the Interior and Administration, which are police and military schools - all together 9 institutions ${ }^{8}$.

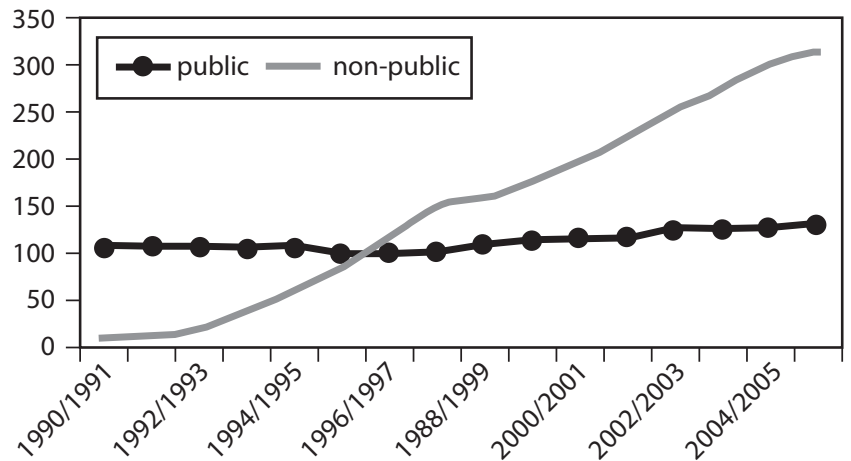

Diagram 1. Public and non-public academies (until the academic year 2004/2005 described as state and non-state academies) Source: http://www.nauka.gov.pl/fileadmin/user_upload/18/66/18662/ publikacja.pdf (visited on 04 June 2010), p. 19.

/uczelnie-artystyczne/wykaz-uczelni-artystycznych.php (visited on 30 August 2010).

6 Uczelnie muzyczne w Polsce [Music universities in Poland], available on the Internet: http://www.poland.gov.pl/Uczelnie,Muzyczne,w,Polsce,10961.html (visited on 30 August 2010).

7 Wykaz uczelni artystycznych [List of artistic universities], available on the Internet: http://www.mkidn.gov.pl/pages/strona-glowna/uczniowie-i-studenci /uczelnie-artystyczne/wykaz-uczelni-artystycznych.php (visited on 30 August 2010).

8 Szkoly wojskowe i policyjne [Military and Police schools], available on the Internet: http://katalog.wp.pl/szkolywojskowe-i-policyjne/ (visited on $31 \mathrm{Au}-$ gust 2010). 
In our country, since 1991 there have been formed and developed private universities ${ }^{9}$ (see diagram 1). Nowadays the number of these schools, with different profiles and educational levels, is estimated at $347^{10}$.

After summing up the already mentioned numbers of the public and non-public academies, we can see that the total number of operating ones is 486 . It seems to be quite an impressive number, and also the number of church-related higher education institutions (which are, with a few exceptions, not governed by the state legislation) should not be forgotten - there are 7 catholic higher schools and 7 schools run by other denominations, as well as a large number of seminaries, convents and monasteries ${ }^{11}$.

In comparison with the last two decades, there is a noticeable rise in the number of non-public academies, which is shown in the first table ${ }^{12}$. The number of academies in the academic year $2005 / 2006$ rose by $297 \%$, compared to the number from the year

9 Szkoły wyższe i ich finanse w 2005 r. Informacje i opracowanie statystyczne [Higher Education Institutions (Schools) and their Finances in 2005. Information and Statistic Papers], ed. by Główny Urząd Statystyczny, (2006): available on the Internet: http://www.nauka.gov.pl/fileadmin/user_upload/18/66/ 18662/publikacja.pdf (visited on 4 June 2010), p. 19.

10 Wykaz uczelni niepublicznych [List of non-public universities], available on the Internet: http://www.nauka.gov.pl/szkolnictwo-wyzsze/system-szkolnictwa-wyzszego/uczelnie/uczelnie-niepubliczne/wykaz-uczelni-niepublicznych/ (visited on 4 June 2010).

11 Uczelnie kościelne [Church universities], available on the Internet: http://www.nauka.gov.pl/szkolnictwo-wyzsze/system-szkolnictwa-wyzszego/ uczelnie/uczelnie-koscielne/ (visited on 4 June 2010).

12 Dane statystyczne o szkolnictwie wyższym [Statistical data about higher education], available on the Internet: http://www.nauka.gov.pl/szkolnictwowyzsze/dane-statystyczne-o-szkolnictwie-wyzszym/ (visited on 30 June 2010). 
$1990 / 1991^{13}$. The table 2 shows us the increase in the number of students at the turn of the years discussed ${ }^{14}$.

Table 1. Statistical data about academies

\begin{tabular}{ccc}
\hline $\begin{array}{c}\text { Academic } \\
\text { year }\end{array}$ & $\begin{array}{c}\text { Number of acad- } \\
\text { emies in total }\end{array}$ & $\begin{array}{c}\text { Non-public } \\
\text { academies }\end{array}$ \\
\hline $1992 / 1993$ & 124 & 18 \\
$1995 / 1996$ & 179 & 80 \\
$2000 / 2001$ & 310 & 195 \\
$2005 / 2006$ & 445 & 315 \\
$2008 / 2009$ & 458 & 326 \\
$2009 / 2010$ & 486 & 347 \\
\hline
\end{tabular}

Source: http://www.nauka.gov.pl/szkolnictwo-wyzsze/danestatystyczne-o-szkolnictwie-wyzszym/ (visited on 30 June 2010).

Table 2. Statistical data about students

\begin{tabular}{cccc}
\hline \multirow{2}{*}{$\begin{array}{c}\text { Academic } \\
\text { year }\end{array}$} & $\begin{array}{c}\text { Students in total } \\
\text { (thousands) }\end{array}$ & $\begin{array}{c}\text { Public } \\
\text { (thousands) }\end{array}$ & $\begin{array}{c}\text { Non-public } \\
\text { (thousands) }\end{array}$ \\
\hline $1990 / 1991$ & 403,8 & 403,8 & \\
$2005 / 2006$ & 1953,8 & 1333,0 & 620,8 \\
$2008 / 2009$ & 1927,8 & 1268,4 & 659,4 \\
\hline
\end{tabular}

Source: http://www.nauka.gov.pl/fileadmin/user_upload/18/66/18662/ publikacja.pdf (visited on 4 June 2010), p. 20.

Nowadays the biggest academic centre is Warsaw with the largest academy - the University of Warsaw. Students in the

13 Szkoły wyższe i ich finanse w 2005 r., p. 20.

14 Szkoły wyższe i ich finanse w 2005 r., pp. 17, 19; Dane statystyczne o szkolnictwie wyższym, passim. 
capital make up 15\% of all students of Polish universities. Apart from Warsaw the major academic centers are: Kraków, Katowice, Poznań, Wrocław, Lublin, Łódź and Gdańsk. They educate in total about $45 \%$ of students ${ }^{15}$.

Aiming to analyze Polish normative and legal acts, I would like to underline the fact that I divided them into three groups. The first group consists of the regulations concerning higher education in Poland. The second group includes a packet of archival laws and regulations. Lastly, the third one includes the legislation in force for all the operating units and workplaces.

The first numerous group includes the Law of Higher Education from $2005^{16}$, which was crucial to the Polish education system. The group includes also the regulation of 2007, concerning conducting the register of non-public academies ${ }^{17}$, the regulation of 2008, concerning the kinds of professional titles given to graduates, exemplar diplomas and certificates issued by educational units ${ }^{18}$, and the regulation of 2006 , concerning academic career documentation ${ }^{19}$.

15 Szkoły wyższe i ich finanse w 2005 r., pp. 23-24.

16 Ustawa $z$ dnia 27 lipca 2005 r. Prawo o szkolnictwie wyższym [The Act of 27 July 2005, Law on Higher Education], “Dziennik Ustaw Rzeczypospolitej Polskiej” (further: Dz.U.), 164 (2005), item 1365.

17 Rozporzadzenie Ministra Nauki i Szkolnictwa Wyższego z dnia 6 marca 2007 r. $w$ sprawie prowadzenia rejestru uczelni niepublicznych i związków uczelni niepublicznych [Regulation of the Minister of Science and Higher Education of 6 March 2007 concerning conducting the register of non-public academies and unions of non-public academies], Dz.U., 52 (2007), item 348.

18 Rozporzadzenie Ministra Nauki i Szkolnictwa Wyższego z dnia 19 grudnia 2008 r. w sprawie rodzajów tytułów zawodowych nadawanych absolwentom studiów i wzorów dyplomów oraz świadectw wydawanych przez uczelnie [Regulation of the Minister of Science and Higher Education of 19 December 2008 concerning the kinds of professional titles given to graduated students, exemplar diplomas and certificates issued by educational units], Dz.U., 11 (2009), item 61.

19 Rozporządzenie Ministra Nauki i Szkolnictwa Wyższego z dnia 2 listo- 
From the regulations mentioned before we can assume what the definitions of public and non-public educational units are; who supervises the unit's activity according to the law, the statute, and the permission given to create a non-public school; and who supervises the legitimacy of spending public funds ${ }^{20}$ (see table 3 ). What is important, in the Law of Higher Education there is a short but crucial provision about university archives, which says that every academy runs its own archive and its activity is regulated by the Act on National Archival Records and Archives ${ }^{21}$.

Table 3. Government departments supervising the activity of the academies

\begin{tabular}{ll}
\hline Minister & Academies \\
\hline - The Minister of National Defense & - military academies \\
- The Minister of Internal Affairs & - governmental service academies \\
- The Minister of Culture and Na- & - art academies \\
tional Heritage & \\
- The Minister of Health & - medical academies \\
- The Minister of Maritime Affairs & - maritime academies \\
\hline
\end{tabular}

Source: Ustawa z dnia 27 lipca 2005 r. Prawo o szkolnictwie wyższym [The Act of 27 July 2005, Law on Higher Education], Dz.U., 164 (2005), item 1365, article 33 .

This extremely important act of law also regulates the matters of the university staff, both university teachers and other employees. In accordance with this act, only licensed documentation

pada 2006 r. w sprawie dokumentacji przebiegu studiów [Regulation of the Minister of Science and Higher Education of 2 November 2006 concerning academic career documentation], Dz.U., 224 (2006), item 1634.

20 Ustawa z dnia 27 lipca 2005 r. Prawo o szkolnictwie wyższym, article 33.

${ }^{21}$ Ibidem, article 88. 
clerks can become employees of university archives, working on the positions of ${ }^{22}$ :

a) Licensed custodian senior, licensed documentarian senior

b) Licensed custodian, licensed documentarian.

The forerunner of the law of 2005 was the Law of Higher Education from 12 September 1990. This act included definitely more information about archives of universities. In the article 68 it was also recorded that every academy acquires its own archive which belongs to the state archival network. This general university units had to do a task of scientific, didactic and service character. The kind, condition, mode of creation, dissolution and transformation were defined by the statute of an academy which acted on the basis of the resolution of the Senate ${ }^{23}$.

One of the most essential regulations when it comes to university archives is the Minister of Science and Higher Education regulation of 2006, concerning academic career documentation, and concerning materials which will become part of the university archive in due course. In this very important act there are included data covering - in quotes - student's personal file, that is the documentation required from a candidate to study, the documentation from the qualification process, the documentation created while studying, a thesis, the documentation from defending the thesis, and a graduation diploma. A student's file has to be stored for fifty years in university archives ${ }^{24}$.

The second group comprises the above mentioned packet of archival laws and regulations. It is composed of the aforesaid Act on National Archival Records and Archives of 14 July 1983. This

22 Ibidem, article 113.

23 Ustawa z dnia 12 września 1990 o szkolnictwie wyższym [The Act of 12 September 1990 on Higher Education], Dz.U., 65 (1990), item 385, article 68.

24 Rozporządzenie Ministra Nauki i Szkolnictwa Wyższego z dnia 2 listopada 2006 r. w sprawie dokumentacji przebiegu studiów, § 2 and § 10. 
act of law divides these archival fonds into two groups: state and non-state. As documented, in the archiving activity in the field of state archival fonds are included such units as: the archives of public academies, which, being current archives of their Alma Maters (art. 35), are described as operating units possessing entrusted archival fonds, forming part of state archival network (art. 15 $)^{25}$. That means that university archives have the right to perpetual storing of records, without any obligation to pass them to state archives. This law was introduced more than half a century ago. At first, these powers were given to academies by the Minister through the regulation of 19 February 1957, concerning state archival fonds; and subsequently the General Director of State Archives gave university archives the right to store the archival materials which were and are created as a consequence of the university activity thanks to the document of 15 March $1958^{26}$.

Therefore, the above mentioned archives, like the state archives, are obliged to conduct archival activities, which comprises gathering, record keeping, storing, arranging, securing and giving access archival materials, with information-sharing activity (art. 23) ${ }^{27}$. The substantive supervision of these activities is exercised by a territorially adequate state archive (in accordance with the rule of territorial provenance) (art. 28) ${ }^{28}$.

25 Ustawa $z$ dnia 14 lipca 1983 r. o narodowym zasobie archiwalnym i archiwach [The Act of 14 July 1983 on National Archival Records and Archives], Dz.U., 97 (2006), item 673, article 15 and 35.

26 Barcik, Miejsce, p. 148; R. Degen, Archiwum uniwersytetu - rola i zadania $w$ zarzadzaniu dokumentacja szkoly wyższej [Archive of the university - the role and tasks in record management of higher school], "Archiwista Polski", 4 (2002), p. 26.

27 Ustawa $z$ dnia 14 lipca 1983 r. o narodowym zasobie archiwalnym i archiwach, article 23.

28 Ibidem, article 28. 
The archival act regulates also the issues of conduct with records created by non-public academies. The archival materials created by these institutions constitute part of the national archival fonds, and not the state ones. They are fully protected. According to the art. 45 of the Act, non-state archives are obliged to record keeping, storing and preserving records. In the case of liquidation, their materials become property of the state and they are included into the state archival fonds (art. 44). All the rules of cooperation between academies' archives and the state archival network are regulated by agreements between their authorities and the Minister of Culture and National Heritage Preservation $\left(\right.$ art. 45) ${ }^{29}$.

Like public higher education institutes, the non-public ones are considered to be obliged to create and conduct current archives. It is stated in the Decision of the General Director of State Archives no. 1, dated 27 May 2002 concerning the rules and the method of setting operating units, local government units and autonomous organization units by the stated archives in which current archives are created ${ }^{30}$. After analyzing websites of such schools, we can assume there is no record there about an archive unit existing within the structure of the institutes.

29 Ibidem, article 44 and 45.

30 Decyzja nr 1 Naczelnego Dyrektora Archiwów Państwowych z dnia 27 maja 2002 r. w sprawie zasad i sposobu ustalania przez archiwa państwowe państwowych jednostek organizacyjnych, jednostek samorzadu terytorialnego $i$ samorządowych jednostek organizacyjnych, $w$ których tworzy się archiwa zakładowe [Decision no. 1 by the General Director of the State Archives of 27 May 2002 concerning the rules and the method of setting up by the state archives operating units, local government units and autonomous organization units in which current archives are created], available on the Internet: http://www.archiwa.gov.pl/lang-pl/prawo/70-akty-normatywne-naczelnego-dyrektora-archiwow-panstwowych.html (visited on 2 September 2010). 
There are also three regulations of the Minister of Culture - of $2002^{31}, 2005^{32}$ and $2008^{33}$ included in the packet of archival laws. The first of them concerns the rules of dealing with records in archives of a given institution, and the subsequent ones inform under what conditions the records should be permanently and safely preserved. The latter of the aforesaid (of 2008) concerns special events and procedures of giving access to archival materials earlier than it was supposed to be done.

Serving as the link in the state archival network, university archives are obliged to implement the regulation of the General Director of the State Archives - the head of the archival network. I mean here the Regulation no 4 by the General Director of the State Archives, dated 18 May 2000, concerning giving access to archival materials in state archives $^{34}$.

31 Rozporzadzenie Ministra Kultury z dnia 16 września 2002 r. w sprawie postępowania $z$ dokumentacja, zasad jej klasyfikowania i kwalifikowania oraz zasad i trybu przekazywania materiałów archiwalnych do archiwów państwowych [Regulation of the Minister of Culture of 16 September 2002 concerning the procedure with documentation, principles of classifying and qualifying and also principles and mode of delivering archival materials to state archives], Dz.U., 167 (2002), item 1375.

32 Rozporzadzenie Ministra Kultury $z$ dnia 15 lutego 2005 r. w sprawie warunków przechowywania dokumentacji osobowej i płacowej pracodawców [Regulation of the Minister of Culture of 15 February 2005 concerning conditions of the storage of personal and pay documentation of employers], Dz.U., 32 (2005), item 284.

33 Rozporzadzenie Ministra Kultury i Dziedzictwa Narodowego $z$ dnia 29 lipca 2008 r. w sprawie określenia szczególnych wypadków i trybu wcześniejszego udostępniania materiałów archiwalnych [Regulation of the Minister of Culture and National Heritage of 29 July 2008 concerning the definition of special cases and the mode of earlier access to the archival material], Dz.U., 156 (2008), item 970.

34 Zarzadzenie nr 4 Naczelnego Dyrektora Archiwów Państwowych z dnia 18 maja 2000 r. $w$ sprawie organizacji udostępniania materiałów archiwalnych 
Besides the above-mentioned regulations, it is crucial to write a few words about chancery and archival norms which includes a chancery (office) instruction with the register of records and the instruction concerning the organization and the field of the archive's activity. As far as the first one is concerned, it is only slightly connected with a university archive because it regulates the cases of dealing with records until the moment of handing them on to a current archive; the register of records and the instruction are extremely important from an archivist's point of view when it comes to organizing work. A properly prepared register can tell an archivist where to turn when the records are badly classified (a parental unit), how to find a unit which produced the records (the symbol of organizing units); an archivist comparing the register of records from a given unit with the register of records to be recycled can easily find out whether proper records were selected or not. The instruction concerning the organization and the field of the archive's activity, as the name implies, includes the information necessary to fulfill the duty of a current archive's employee in a proper way.

The third and the last group of laws includes, as I mentioned before, the acts of law obligatory for all the operating units. That is health and safety registration ${ }^{35}$, fire protection regulations ${ }^{36}$, law

$w$ archiwach państwowych [Regulation no 4 by the General Director of the State Archives of 18 May 2000 concerning giving access to archival materials in state archives], available on the Internet: http://www.archiwa.gov.pl/lang-pl/prawo/ 70-akty-normatywne-naczelnego-dyrektora-archiwow-pastwowych.html (visited on 2 September 2010).

35 Rozporządzenie Ministra Nauki i Szkolnictwa Wyższego z dnia 5 lipca 2007 r. w sprawie bezpieczeństwa i higieny pracy w uczelniach [Regulation of the Minister of Science and Higher Education of 5 July 2007 concerning safety and occupational health at universities], Dz.U., 128 (2007), item 897.

36 Rozporzadzenie Ministra Spraw Wewnętrznych i Administracji $z$ dnia 16 czerwca 2003 r. w sprawie ochrony przeciwpożarowej budynków, innych 
of personal data protection ${ }^{37}$, law of copyright ${ }^{38}$, classified information protection ${ }^{39}$ and press law ${ }^{40}$. This group includes also all regulations issued by the head of an academy who is in charge of all the university, the archive, statutes and organizing regulations.

To summarize, it is essential to emphasize that the archives of public academy are independent units subordinated to the authority of the rector or chancellor. These issues are regulated by the statute of an academy and by its organizing regulations. The form of an archive is also dependent on the kind and status of an academy. An archive serves as an educational establishment whose task is to deepen and popularize the knowledge about its parent college. It has the right to take the initiative in some cases and suggest problems to the college authorities, it can cooperate with many other state or university's archives, with individuals, companies, social groups, state organizations, NGOs and other institutions.

This issue seems to be far less favorable for non-public academies' archives.

obiektów budowlanych i terenów [Regulation of the Minister of the Interior and Administration of 16 June 2003 concerning fire protection of buildings, other construction objects and fields], Dz.U., 121 (2007), item 1138.

37 Ustawa $z$ dnia 29 sierpnia 1997 r. o ochronie danych osobowych [The Act of 29 August 1997 on the law of personal data protection], Dz.U., 133 (1997), item 883.

38 Ustawa $z$ dnia 4 lutego 1994 r. o prawie autorskim i prawach pokrewnych [The Act of 4 February 1994 on the law of copyright and related laws ], Dz.U., 24 (1994), item 83.

39 Ustawa $z$ dnia 22 stycznia 1999 roku o ochronie informacji niejawnych [The Act of 22 January 1999 on the protection of secret information.], Dz.U., 11 (1999), item 95.

40 Ustawa $z$ dnia 26 stycznia 1984 r. Prawo prasowe [The Act of 26 January 1984, Press law], Dz.U., 5 (1984), item 24. 
It should be clearly stated here that the archives of the abovementioned nine higher education schools subordinated to the National Defense and the Ministry of the Interior and Administration are the so-called separate archives. All the issues concerning their organizing and functioning are discussed in regulations issued by these resorts.

Summing up my lecture, it is crucial to emphasize the essential role of universities' archives. After a big political and economical change in Poland, people do not limit themselves to focus only on the administrative service at universities as the legal changes forced them to be more open for others and for external ideas. Hence certificates, confirmations, authentications from the collected archival supplies were issued on a daily basis.

The archives under discussion are the units storing records. This is an important element of the university's memory, and storing is connected with arranging and giving access to that documentation. These institutions were created not only for saving but also giving access to this material to a wide range of people, which is being done by, for instance, organizing exhibitions and issuing archive-themed publications.

As I mentioned before, a fund includes the personal documentation of a student, academy's employee or a graduate, but also documents prominent for a local community. Among them we can enumerate films, voice recordings, private papers, manuscripts and even paintings and models. As can be easily seen, these are very valuable materials, a rich source to be considered when examining local history, social groups (staff and students) or the history of a university. An archive can be surely considered a topographic memory carrier or a constant, non-scattered memory of a university. Thus it is very important to take care of the unit's efficient organization and functioning in compliance with the law in force. Indeed, the art. 34 of the archival act states 
that current archives should be dependent to the heads of organizing units. It seems to be right because the higher a place the unit takes in the structure, the bigger its chances are to raise its prestige and to raise the prestige of its employees - in this case archivists. It can also give an opportunity to build a better image of the archive. In the case of academy's archives, only part of them constitute independent administrative units subordinated to the rector. The remaining group is considered something like the necessary evil. 


\section{ARCHIWA POLSKICH UNIWERSYTETÓW W ŚWIETLE PRZEPISÓW PRAWA}

(STRESZCZENIE)

Celem artykułu jest zapoznanie czytelnika z obowiązującymi przepisami prawno-normatywnymi regulującymi organizację i funkcjonowanie archiwów uczelnianych w Polsce. Omówiony został polski system szkolnictwa wyższego z uwzględnieniem danych statystycznych publicznych i niepublicznych uczelni. Następnie przedstawione zostały akty normatywno-prawne mające wpływ na funkcjonowanie archiwów uniwersyteckich, według podziału na trzy grupy. Najpierw omówiono przepisy dotyczące szkolnictwa wyższego w Polsce. Drugą grupę stanowi pakiet ustaw i rozporządzeń archiwalnych. Do trzeciej zaś grupy zaliczone zostały przepisy obowiązujące wszystkie jednostki organizacyjne.

Analiza podstaw prawnych wykazała niezwykle istotną rolę, jaką mają do spełnienia archiwa uniwersyteckie, działające przy każdej uczelni, będące jednostkami organizacyjnymi posiadającymi powierzony zasób archiwalny i wchodzącymi w skład państwowej sieci archiwalnej. Archiwum uczelniane pełni zarówno rolę placówki naukowej, której jednym z zadań jest pogłębianie i popularyzacja wiedzy na temat rodzimej uczelni, jak i funkcję archiwum zakładowego. W artykule poruszona została także kwestia archiwów uczelni niepublicznych.

Opracowane przez Autorkę//Prepared by the Author 